\title{
EXPLORING THE EFFECTIVE USE OF MOBILE DEVICES BY PREVIOUSLY DISADVANTAGED ENGLISH LANGUAGE STUDENT EDUCATORS THE CONSTRUCTIVIST WAY
}

M. Sylvia Lediga \& L. Junia Ngoepe

University of Limpopo

\begin{abstract}
The use of smartphones and tablet computers is at the leading edge of technology and studying. The majority of students who study English in previously disadvantaged institutions (PDIs) possess handheld mobile devices, and this augurs well for the effective use of these devices. The use of handheld mobile devices can revolutionise the learning and teaching of English language among the students, who usually queue to use desktop computers. The use of handheld mobile devices could also foster collaborative and independent learning. The aim of this paper is to discuss the responses of English language student educators to a questionnaire on the use of handheld mobile devices at a PDI in South Africa.
\end{abstract}

\section{INTRODUCTION}

If English language student educators can effectively use handheld mobile devices in learning and teaching the language, they could help ease congestion and queueing periods at computer laboratories, since most students in previously disadvantaged institutions (PDIs) appear to possess handheld mobile devices (Zhang \& Perez-Paredes, 2019) and are on the move. Fostering the use of handheld mobile devices could in the process render student educators relevant even before they qualify to teach. This experience could inadvertently seed selfdirected and collaborative learning among the students. Above all, it could develop into a cost-effective exercise for the PDIs and, by extension, South Africa. Thus, this paper is presented in terms of the significance of technology, mobile devices, mobile learning, English language student educators in context, rationale for theory, methodology, findings and conclusion.

\section{SIGNIFICANCE OF TECHNOLOGY}

One of the issues consistently raised as a barrier to effective language learning is the use of passive learning pedagogies and a lack of self-directed learning in curricula. Increasingly, educators are moving towards technology to engage their students in more effective learning. They also acknowledge that in order for technologically enhanced pedagogies to be effective, it is important for them to be congruent with the ways in which learners actually use their learning devices (Albedah \& Lee, 2017: 152). Some institutions and even countries equip students with a particular model of phone or tablet in order to allow the institution to make far greater use of mobile learning and assessment. Smartphones are also used as a person's primary means of gaining access to social networking sites (de Chazal, 2014: 329). 
Technology has arguably changed the way in which students learn and educators teach in the 21 st century. This has placed a premium on the role of technology in English language learning and teaching since the advent of computer technology. However, the use of technology in education remains an important issue today, considering the implications of quick and easy online access to information for knowledge and learning, as well as the effect of technology on students' development. Therefore, there is fertile ground for exploring the use of handheld mobile devices in the learning of English. Moreover, cyberspace is the natural habitat of 21 st-century students. Although economic differences between developed and developing countries materially influence the digital devices and networks students have access to, the internet is a worldwide presence (Mishan, 2017: 14). Thus, the advent of the internet in the 1990s led to major developments in the world of communication (Kolan \& Dzandza, 2018).

Technologies are not necessarily useful unless they can effectively be used. For example, equipping every classroom with an interactive whiteboard may or may not result in better teaching and learning (de Chazal, 2014: 319). Since technology is a tool which can provide an innovative pedagogical means to enhance learning of languages, it is considered one of the most important drivers of social and linguistic change in this digital age. Therefore, it can help ameliorate some language difficulties (cf. Gunina, 2015). Learning technologies are thus regarded as teaching and learning resources (de Chazal, 2014: 319).

In most teaching contexts in South Africa and internationally, the majority of students are based in institutions and attend face-to-face classes. Although most direct teaching remains face to face through lecturers, seminars and tutorials, teaching and learning is increasingly supported, supplemented and complemented through the use of technologies (cf. de Chazal, 2014: 320). Thus, if given a chance, University of Limpopo (UL) English language student educators' teaching and learning can be supported, supplemented and complemented through the use of technologies.

Furthermore, mobile learning is regarded as an effective and engaging method of enhancing language teaching and learning and fostering self-directed language learning. It has also been noted that mobile learning can be particularly effective for language teaching and learning in contexts where students have limited natural opportunities to use English outside the classroom (Richards, 2015), such as in the UL context.

The use of mobile devices redefines the way information is consumed, disseminated and used (Geist, 2011). This is a trend in higher education which redefines the manner in which learning takes place and how instruction is delivered (Miller, 2012). Moreover, the use of these mobile devices in learning tends to motivate students and engage their attention while focusing on solving problems. It also improves their memory and reading and writing skills (Saleh \& Alias, 2012; see Appendix A \& Appendix B). Thus, it is essential to conduct research in this area (Geist, 2011) that focuses on the use of handheld mobile devices by university second-level student educators. 


\section{USE OF HANDHELD MOBILE DEVICES}

The role of information and communication technology in education has created an innovative means of learning through the use of mobile devices (Oriogo, et al., 2018). These devices are small, are inexpensive and are often on-the-go computers. The devices have become popular; they can normally retrieve wireless internet signals, can be used to surf the web, and can be used as calculators and word processors. Additionally, mobile handheld devices tend to increase in functionality within lecture halls and can be used as teaching and learning tools (Traxler, 2007: 4). Similarly, handheld mobile devices can be conveniently used as tools for learning English in language classes at UL.

The effective and creative use of handheld mobile devices can revolutionise the learning and teaching of English language at institutions of higher learning, especially PDIs. English language learners and educators are likely to benefit from how these devices are used. Such an experience could be cost-effective for educational institutions, funders, parents, guardians and the students themselves. Digital technologies are increasingly becoming part of the way people communicate and of the context in which language is used. The case in point is the higher education sector where technology is utilised for daily teaching and learning. For most students, digital tools are an integral way to study (de Chazal, 2014: 319).

For learning to be effective, it needs to be student-centred, knowledge-centred, assessmentcentred and community-centred. These four characteristics of effective learning indicate that learning is not an individual journey; rather, it is an individual enterprise that is achieved with environmental and community support (Nordin et al., 2010: 132). For example, learningoriented assessment represents a possible way forward by focusing all assessment processes on the advancement of student learning (Carless, 2015: 10). Thus, handheld mobile devices can enrich the English language learning environment at PDIs as well as the English language academic community.

Nordin et al. (2010: 131) note that, since contemporary students are always on the move, their learning must adapt to their mobility. Similarly, the learning activities of UL English First Additional Language (EFAL) student educators on and off campus should adapt to their mobility. Thus, learning stands to happen almost anywhere due to the use of increased computing devices such as handheld mobile devices. Oriogo et al. (2018) assert that the increased use of mobile devices can make learning more accessible and e-resources easily shared.

Moreover, 'mobile', in the context of mobile devices, refers to the portability of these devices and how easy it is to transport them from one place to another. The concept of mobility also suggests that the devices and their operating technologies were designed for personal rather than shared usage (Naismith, et al., 2004: 2; cf. Liu et al., 2014). The portability of mobile devices enables students to use mobile English learning resources at short intervals (cf. Zhang \& Perez-Paredes, 2019: 1). This, however, does not guarantee the effective use of mobile devices to acquire language knowledge (Chen, 2013; Stockwell, 2008). In light of the increasing ownership of mobile devices among students, understanding students' selfdirected use of mobile-assisted language learning is of great significance (Zhang \& PerezParedes, 2019: 2).

Mobile devices have come to stay and are mostly viable tools for learning that can be used as means of learning languages. It is therefore necessary for students to make good use of 
handheld devices for academic purposes (Oriogo et al., 2018; see Findings). The widespread use of mobile and wireless devices in education has led to revolutionary changes regarding teaching and learning. Due to their pervasiveness, mobile phones are considered potentially valuable learning tools. However, students' personal use of mobile phones and their applications for learning benefit remain open to research (Rahimi \& Miri, 2014: 1469). To this end, the use of handheld mobile devices by EFAL student educators is explored in this paper.

\section{MOBILE LEARNING}

The teaching and learning environments of the 21 st century are changing rapidly as a result of unprecedented opportunities in the advancement of information and communication technologies created for education. The fast evolution of mobile devices is opening up a whole new world of new learning experiences with technology (Rahimi \& Miri, 2014: 1469). Hence, some research on the use of mobile handheld devices can be conducted in a PDI such as the UL.

Definitions of mobile learning range from spatial, to technical, to context-driven perspectives. The device aspect relates to various physical and technological characteristics of mobile devices. However, the definitions mainly focus on the notions of mobility and wireless ability. If one separates 'mobile learning' into the concept of 'mobile' and 'learning', the learning aspect is the most important concept in the developing world. The computing device just happens to be mobile (Ford \& Leinonen, 2009: 196; Perez-Paredes et al., 2019).

In most teaching and learning contexts, the technologies that are potentially available probably far outnumber those that are actually used. It is implicit that teachers do not make full use of the technologies available (de Chazal, 2014: 319). This therefore provides fertile ground for the use of technologies by UL student educators.

In a blended learning approach, the digital and traditional aspects of a course will be designed to work in tandem, and students who miss face-to-face sessions are likely to miss important aspects of the course (de Chazal, 2014: 321). On the other hand, navigating electronic databases and using search terms involve specific skills and techniques which imply that students need to learn how to carry out effective searches. Students need the skills to read, interpret, make notes, summarise and synthesise arguments from different sources. Summarising and synthesising are uniquely important with digital readings as it is easy for students to copy and paste material (de Chazal, 2014: 321).

The possibilities for using mobiles to engage students are endless (Drury, 2012). Naismith et al. (2004: 2) argue that there are six types of learning which can be undertaken with the use of handheld mobile devices: behaviourist, constructivist, situational, collaborative, informal and lifelong, and learning and teaching support (cf. Methodology).

Since mobile learning is not currently formally embraced by the South African Department of Education, it is implicitly not part of the formal EFAL curriculum. This warrants an exploration of the use of mobile devices for learning (cf. Richards, 2015) including at PDIs. 


\section{UL ENGLISH LANGUAGE STUDENT EDUCATORS IN CONTEXT}

English language student educators at UL are students who have enrolled for a Bachelor of Education degree. Most of these students are from an underprivileged background, as they attended less-resourced rural or peri-urban high schools. The majority of them reach university level without any knowledge of how to operate a computer or a laptop but possess handheld mobile devices (Lediga, 2018: 14).

Second-level EFAL students register for English for Educators and Method of English modules. In English for Educators, students are taught English content, such as literature and language. In literature, they are taught poems, short stories and drama, whereas in language, lecturers use extracts from books, articles and so forth to teach language (grammar) in context (University of Limpopo Calendar, 2016). In the Method of English module, students are taught steps in lesson planning, learning outcomes and assessment standards in the Grade 7-9 curriculum, as well as an introduction to the teaching of poetry, short stories and language (grammar) (University of Limpopo Calendar, 2016).

This paper explores whether EFAL student educators have mobile handheld devices that can connect to the internet or not. This implies that only student educators who had mobile handheld devices could participated in the study. Thus, students who had access to the internet and had handheld mobile devices were able to take part. These respondents were registered for an English for Educators module in the Languages, Social Sciences and Management Sciences Department in the School of Education, Faculty of Humanities; they were registered for a Bachelor of Education majoring in English and either History, Life Orientation, Geography, Tshivenda or Xitsonga (see Findings - Table 3).

\section{METHODOLOGY}

This paper adopts an exploratory design anchored in social constructivism. An exploratory design stands to be effective for exploring the uncharted area (Dornyei, 2007: 308) of the use of handheld mobile devices by EFAL second-level students since little is known about this phenomenon (cf. Dornyei, 2007: 39). Thus, the use of handheld mobile devices by student educators to learn EFAL remains challenging. Hence, the use of handheld mobile devices by EFAL student educators was explored. EFAL student educators first completed a questionnaire on the use of handheld devices (see Appendix A).

Social constructivist learning is premised on Vygotsky's developmental theory. In line with this theory, learning is first mediated by tools and signs within their contexts. Thus, learning activities and materials should be contextualised; they should be relevant to students' daily lives (Vygotsky, 1978). For example, students can use handheld mobile devices to verify spellings of words in an EFAL class. In line with constructivism, the students generate and acquire EFAL knowledge through handheld mobile devices when they perform tasks (cf. Richards, et al., 2012: 308). Students construct their own understanding and knowledge through experiencing things (Adom, et al., 2016). Their learning develops through social interaction and dialogue, in which students gradually absorb others' knowledge and coconstruct new knowledge (Bonk \& Cunningham, 1998: 38), for example while using handheld mobile devices. In this paper, the tool is the mobile handheld device.

Social constructivism is based on reality, knowledge and learning. It is also about knowledge which is created when individuals generate meaning through interaction with each other and 
with their environment. Further, it is about learning as a social process that refers to meaningful learning that takes place when individuals engage in social activities such as interaction and collaboration (Amineh \& Asl, 2015: 13). Therefore, the use of handheld mobile devices, which are tools present in the students' environment, fosters interactive as well as collaborative learning.

Hang et al. (2017: 2) assert that social constructivism can be characterised by five key features, namely, that learning is social, that knowledge is experience-based, that knowledge is constructed by learners, that all aspects of a person are connected, and that learning communities should be inclusive and equitable. Texts are socially produced in particular communities and depend on students for their sense, leading to students learning more about how knowledge is constructed, negotiated and made persuasive (cf. Appendix A). Thus, the EFAL students can experience the use of handheld mobile devices as well as construct knowledge, and both activities can occur in a classroom.

A qualitative open-ended questionnaire was used to collect data from second-level EFAL student educators. It was regarded as an appropriate tool for enabling students to explain in their own words how the use of handheld devices is influential or beneficial in their learning of EFAL. The questionnaire consisted of six main questions, arranged thematically. Student teachers' responses to the questionnaire constitute some of the data collected and analysed in this paper. In addition, a Criterion-referenced Test was designed to assess the use of mobile handheld devices among the EFAL student educators. The researcher developed a marking guide and invigilated the 45-minute test.

\section{QUESTIONNAIRE FINDINGS AND TEST RESULTS}

In this paper, the results are made up of questionnaire findings and test results on the use of handheld mobile devices. The raw scores in the questionnaire and the test are discussed as percentages.

\section{Questionnaire findings}

Results of the questionnaire are mainly presented in terms of biographical details and usage of devices.

\section{Biographical data}

The biographical data are made up of language choices per gender, Grade 12 level scores and other major courses for which students were registered. This information is presented below.

Table 1: Language choices at NCS level per gender

\begin{tabular}{|l|l|l|l|l|l|l|l|}
\hline Grade & $\begin{array}{l}\text { NCS language } \\
\text { options }\end{array}$ & $\begin{array}{l}\text { No. of male } \\
\text { students }\end{array}$ & $\boldsymbol{\%}$ & $\begin{array}{l}\text { No. of female } \\
\text { students }\end{array}$ & $\boldsymbol{\%}$ & $\begin{array}{l}\text { Total } \\
\text { students }\end{array}$ & $\%$ \\
\hline $\begin{array}{l}\text { Grade } \\
\text { English passed }\end{array}$ & EFAL & 31 & 94 & 34 & 87 & 65 & 90 \\
\cline { 2 - 7 } & EHL & 02 & 6 & 05 & 13 & 7 & 10 \\
\hline
\end{tabular}

As shown in Table 1, of the total number of respondents to the questionnaire, $46 \%$ were male students and 54\% were female students. Of the male students, 94\% wrote the EFAL examination in Grade 12, while 6\% wrote the English Home Language (EHL) examination. Of the female students, $87 \%$ wrote the EFAL examination whereas $13 \%$ wrote the EHL 
examination. This implies that PDIs such as UL are mainly patronised by students who went to public schools and wrote an EFAL examination at Grade 12 level (cf. Ngoepe, 2017: 181).

Table 2 portrays respondents' Grade 12 level English scores.

Table 2: Grade 12 level scores

\begin{tabular}{|c|c|c|c|c|c|c|}
\hline \multirow[t]{2}{*}{$\begin{array}{l}\text { Grade } 12 \\
\text { level scores }\end{array}$} & \multicolumn{2}{|c|}{$\begin{array}{l}\text { No. of male } \\
\text { students }\end{array}$} & \multicolumn{2}{|c|}{$\begin{array}{l}\text { No. of female } \\
\text { students }\end{array}$} & \multirow[t]{2}{*}{$\begin{array}{l}\text { Total no. of } \\
\text { students }\end{array}$} & \multirow[t]{2}{*}{$\%$} \\
\hline & EFAL & EHL & EFAL & HL & & \\
\hline Level 7 & 04 & 01 & 05 & 03 & 13 & 18 \\
\hline Level 6 & 26 & - & 22 & 03 & 51 & 71 \\
\hline Level 5 & 02 & - & 04 & - & 06 & 8 \\
\hline Level 4 & 01 & - & 01 & - & 02 & 3 \\
\hline
\end{tabular}

From Table 2, it is clear that $71 \%$ of the respondents attained a level 6 score, followed by $18 \%$ who passed at level 7 . Eight $(8 \%)$ obtained level 5, while $3 \%$ scored a level 4 . A few students $(3 \%)$ were at level 4 , followed by the $8 \%$ who attained level 5 . The remaining respondents (18\%) scored level 7, a number which was much lower than those who scored level $6(71 \%)$. Thus, the majority of the students attained a Grade 12 level 6 score in EFAL and EHL (cf. Ngoepe, 2017).

Table 3 portrays data with regard to other major courses for which the participating students were registered.

Table 3: Students' other major courses

\begin{tabular}{|l|l|l|l|l|l|}
\hline \multirow{5}{*}{} & Course & $\begin{array}{l}\text { No. of male } \\
\text { students }\end{array}$ & $\begin{array}{l}\text { No. of female } \\
\text { students }\end{array}$ & $\begin{array}{l}\text { Total } \\
\text { students }\end{array}$ & $\%$ \\
\hline \multirow{3}{*}{$\begin{array}{l}\text { Other } \\
\text { major(s) }\end{array}$} & Geography & 03 & 13 & 16 & 22 \\
\cline { 2 - 6 } & History & 09 & 05 & 14 & 19 \\
\cline { 2 - 6 } & Life Orientation & 07 & 10 & 17 & 24 \\
\cline { 2 - 6 } & Sepedi & 07 & 06 & 13 & 18 \\
\cline { 2 - 6 } & Xitsonga & 06 & 02 & 08 & 11 \\
\cline { 2 - 6 } & Tshivenda & 02 & 02 & 04 & 06 \\
\cline { 2 - 6 } & Total & 34 & 38 & 72 & 100 \\
\hline
\end{tabular}

Regarding the major courses for male and female students combined, $24 \%$ majored in Life Orientation, 22\% in Geography, $19 \%$ in History,18\% in Sepedi, 11\% in Xitsonga and 6\% in Tshivenda.

Geography (33\%) was the most popular subject among female students, followed by Life Orientation (26\%), while Sepedi (15\%) and History (13\%) were almost equally popular. Equal percentages of female students studied Xitsonga (5\%) and Tshivenda (5\%). However, History $(27 \%)$ was the most popular subject among male students, followed by Life Orientation (21\%) and Sepedi (21\%), which were equally popular. Thus, Geography was the most popular, followed by Life Orientation among female students. In addition, the student educators' environment is multilingual, and they come from a diverse language background (Ngoepe, 2017: 180).

Figure 1 gives an indication of the types of mobile handheld devices used by the participating students. 


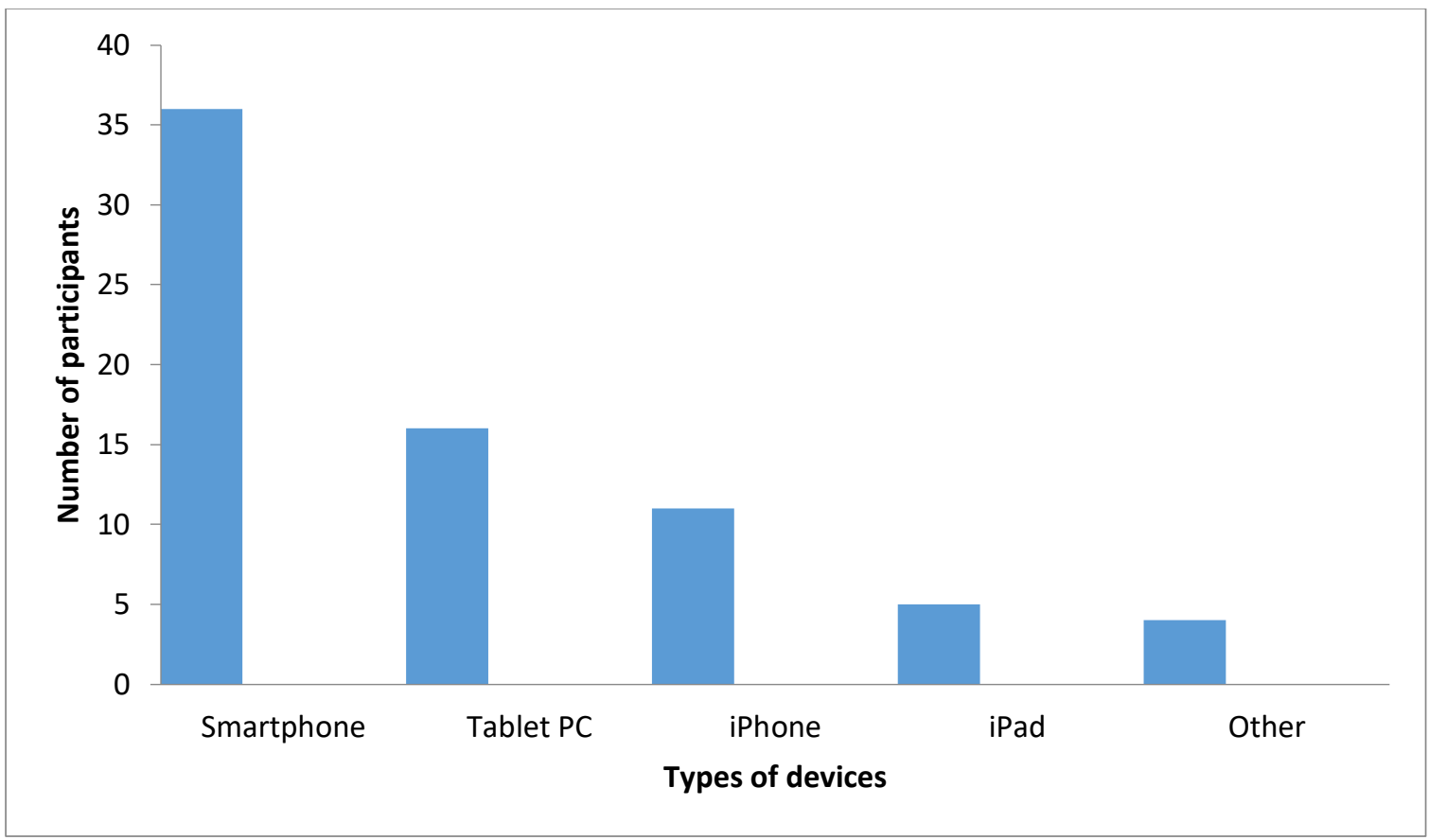

\section{Figure 1: Types of handheld mobile devices}

As shown in Figure 1, it came to the fore that 36 students (50\%) used smartphones, $16(22 \%)$ used tablet PCs, $11(15 \%)$ used iPhones, five $(7 \%)$ used iPads and the remaining four $(6 \%)$ used different handheld devices that were not stipulated in the questionnaire. This indicates that the respondents used smartphones, tablet PCs, iPhones, iPads and other mobile devices which were not specifically mentioned as tools to access information from the internet. UL students use various handheld mobile devices, irrespective of the differences between developed and developing countries (cf. Mishan, 2017).

Figure 2 provides information with regard to reasons why students choose particular devices.

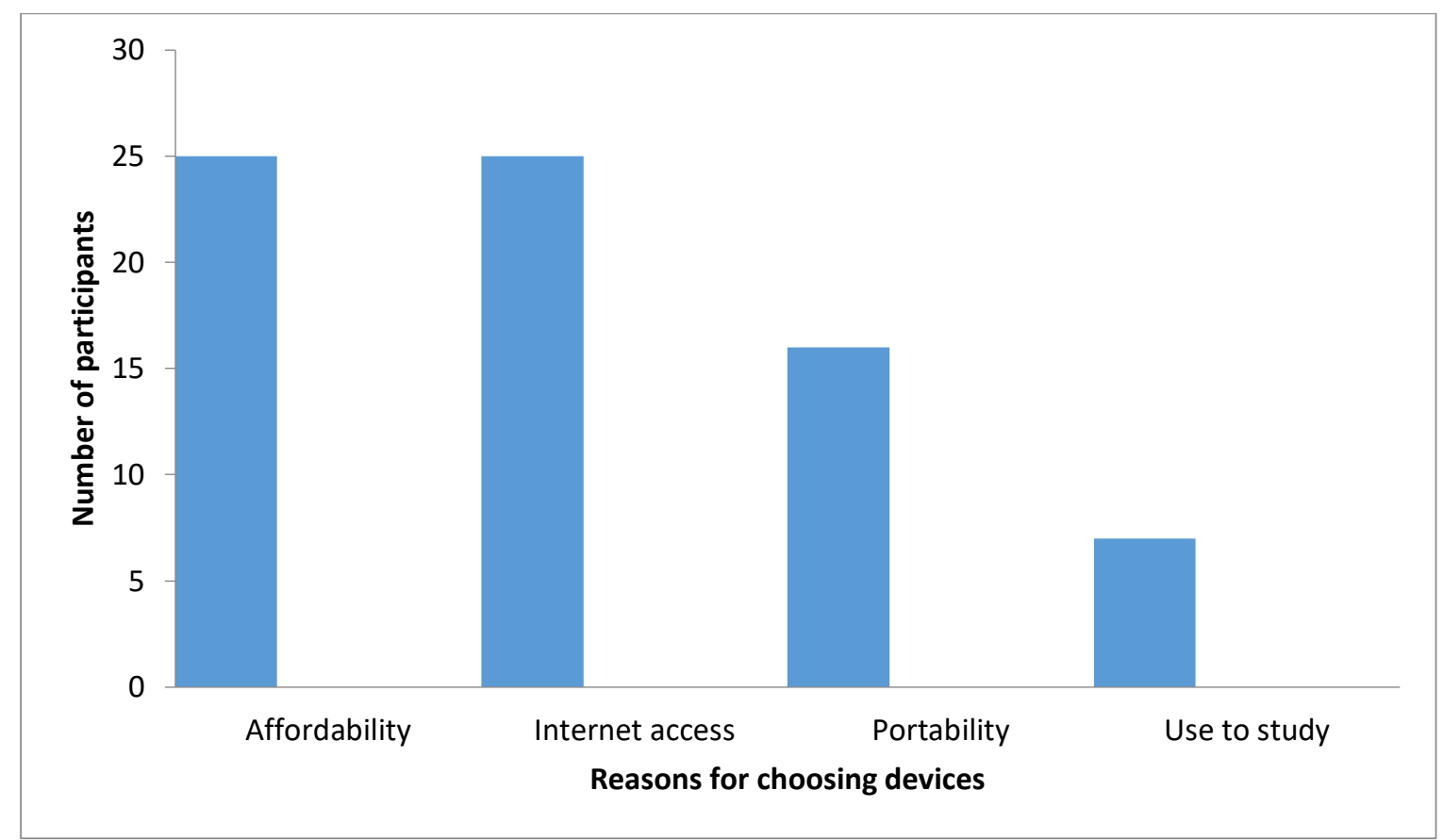

Figure 2: Reasons students chose the device 
Various reasons why students chose a particular device are presented in Figure 2. Equal numbers of students chose devices for affordability and ease of internet access, as 25 students (34\%) chose devices because of their affordability and another $25(34 \%)$ chose devices for ease of internet access. A considerably lower number, 16 (22\%), chose devices on the basis of portability and an even lower number, seven (10\%), chose devices based on their use for study purposes. Although relevant studies regarding English learning resources are still lacking (Zhang \& Perez-Paredez, 2019), the use of the devices to study English as well as the various uses of the devices support mobile learning at an institutional level (cf. de Chazal, 2014. This is why 'digital native' implies a generation comfortable with technology (Mishan, 2017: 14).

Furthermore, $72(100 \%)$, that is all the respondents used their devices to study English. Forty five $(62 \%)$ of the $72(100 \%)$ respondents downloaded English-learning Applications on their devices; 29 (40\%) downloaded the dictionary, $4(6 \%)$ downloaded their prescribed texts and $1(1 \%)$ respondent downloaded the plagiarism checker. However, $11(15 \%)$ respondents did not indicate whether they downloaded any Applications or not.

Figure 3 provides information on how frequently the respondents used their devices.

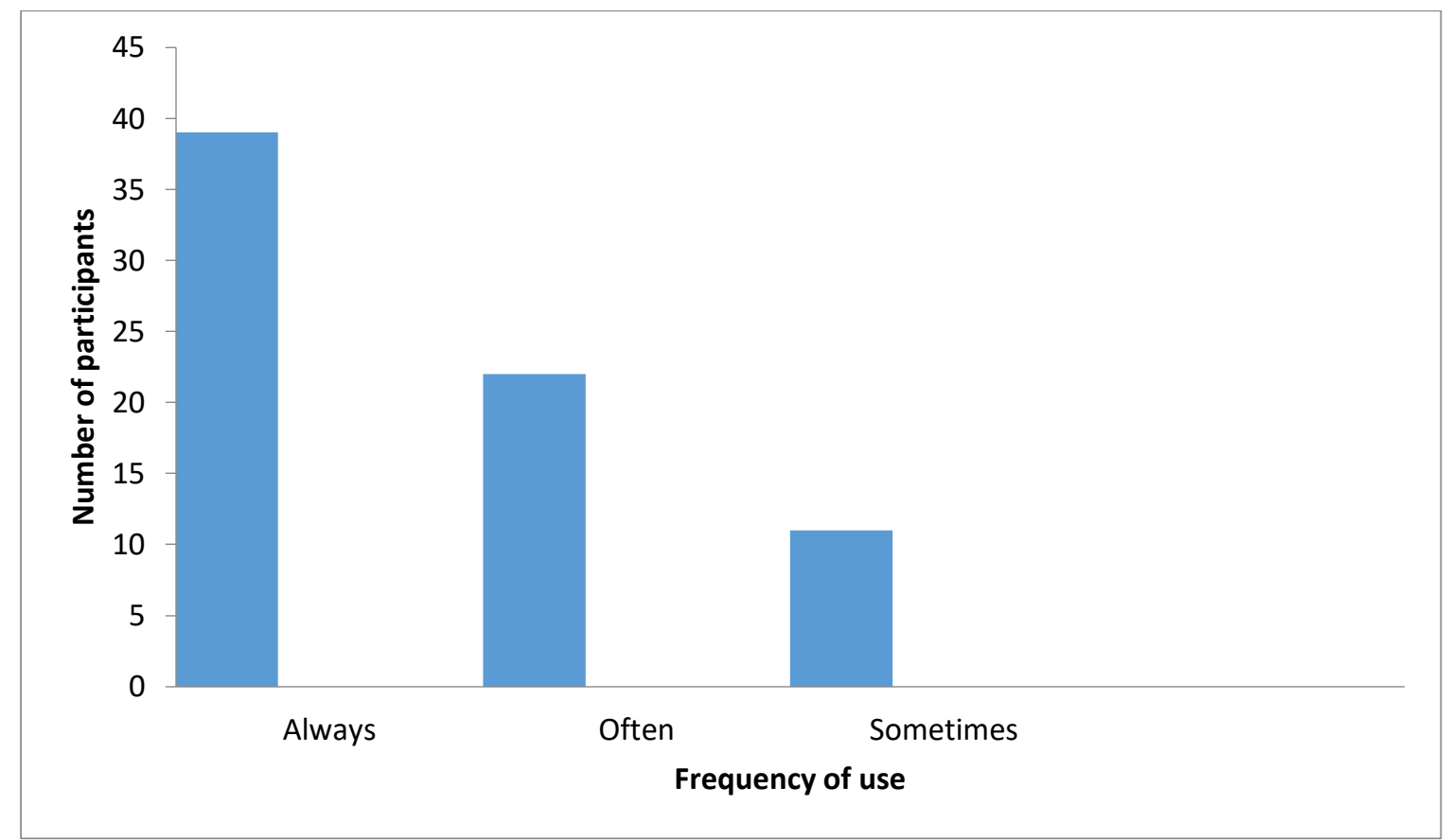

\section{Figure 3: Frequency of use}

Thirty-nine of the respondents (54\%) always used their handheld mobile devices, $22(31 \%)$ used them often and $11(15 \%)$ used the devices sometimes. Thus, more than 36 students $(50 \%)$ always used their devices for learning. In addition, 35 of the respondents (48\%) used their handheld mobile devices to look up information while in class, whereas 30 (42\%) did not. The other seven respondents $(10 \%)$ did not respond to the question. The respondents used their devices in various degrees; most of them always used the devices, a reasonable number often used the devices and a negligible number sometimes used them. Technology, such as mobile devices, aids language learning by providing teaching resources (LarsenFreeman \& Anderson, 2016). Since cyberspace is the natural habitat of 21 st-century students 
(Mishan, 2017), mobile devices have come to stay and are viable tools for learning (Oriogo, et al., 2018). Consequently, the widespread use of mobile devices tends to lead to revolutionary changes in teaching and learning (Rahimi \& Miri, 2014).

Figure 4 portrays the data obtained regarding whether the devices were used for communication purposes.

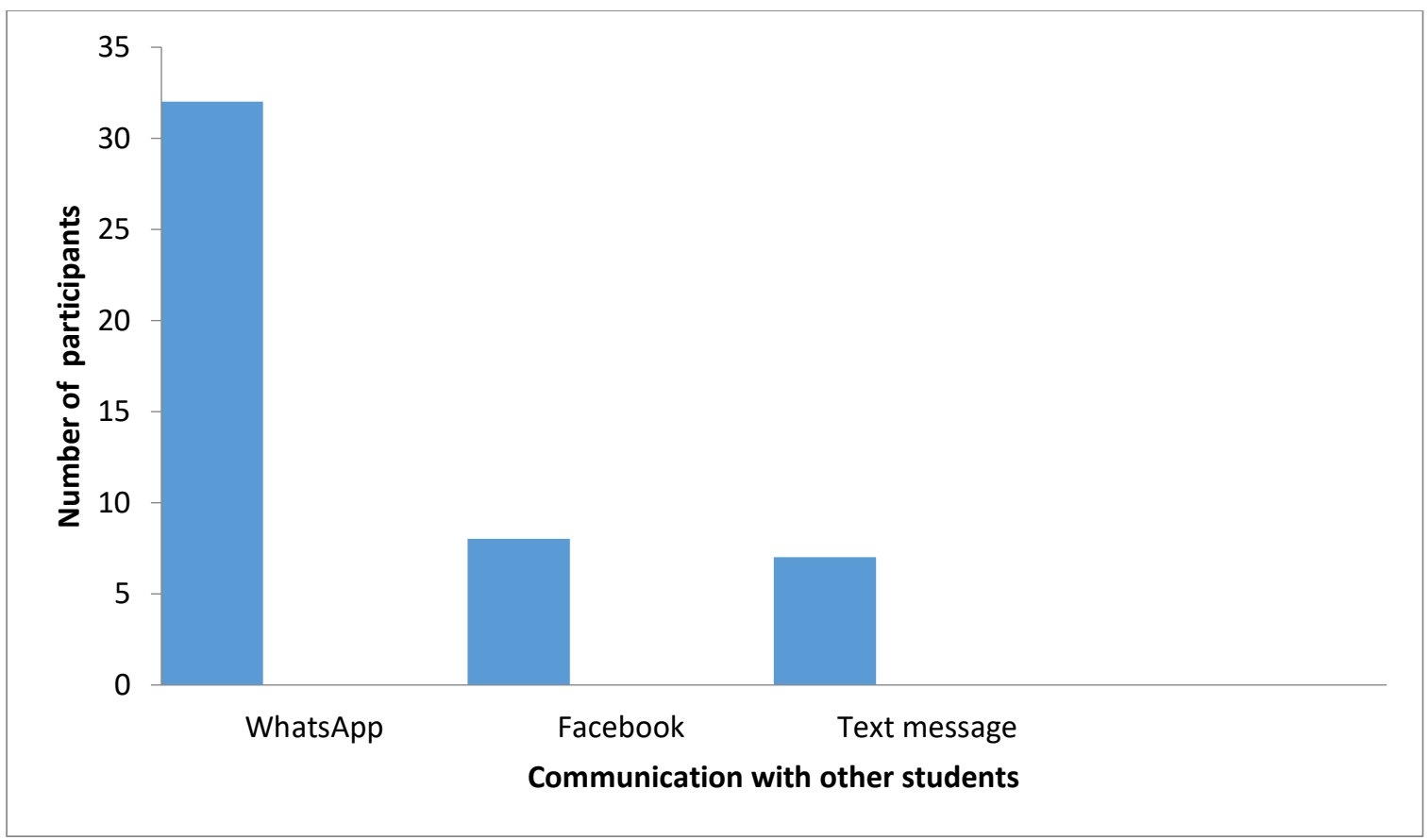

Figure 4: Communication with other students

Figure 4 shows that 47 of the respondents $(65 \%)$, consisting of $32(44 \%)+8(11 \%)+7$ $(10 \%)$, used the devices to communicate with other students, while four $(6 \%)$ did not. From the $47(65 \%)$ respondents who used their devices to communicate, 32 (44\%) used group WhatsApp, 8 (11\%) used Facebook and seven (10\%) used text messages. Twenty-five (35\%) respondents did not state whether their devices were used for communication with other students or not. Given that digital native interaction is conducted via messages whose chief communicative purpose is to stimulate response (Mishan, 2017: 15), the advent of the internet led to major developments in the world of communication (Kolan \& Dzandza, 2018). Thus, the role of information and communication technology in education has created an innovative means of accessing learning sources through the use of mobile technology (cf. Oriogu et al., 2018).

Only 36 respondents $(50 \%)$ used their devices to keep track of their class schedules. Seven of them $(10 \%)$ stated that they downloaded the general timetable from the examination section and also kept track of the class schedule. Twenty-nine respondents (40\%) mentioned that they drew their personal timetables and took pictures of these tables with their devices. They stored the pictures in their devices to keep track of their class schedules.

Almost all the respondents used their devices to search for information; only 1 respondent (1\%) did not use the device to search for information anytime and the remaining 71 (99\%) used the devices to search for information anytime. On a scale of 1 to 5, with 1 being the least useful and 5 the most useful, the respondents rated the usefulness of the devices for learning as follows: $42(58 \%)$ rated the devices as useful in their learning, while a further $30(42 \%)$ 
said that they weremost useful. Fifty respondents (69\%) used mobile handheld devices to record their English class lectures, while 20 (28\%) did not. Only two respondents (3\%) did not mention whether they used the devices to record information or not. Thirty-three $(46 \%)$ of the respondents recorded in-class activities while 39 (54\%) did not. Examples of the lessons recorded are that $50(69 \%)$ recorded class presentations whereas $22(31 \%)$ recorded the lecturer while presenting lessons. In addition, of the $52(72 \%)$ respondents who used their devices for notetaking, 28 (39\%) used Word documents to take notes, 21 (29\%) photographed the slides presented by the lecturer and only four percent recorded the lesson presented by the lecturer. The remaining 20 (28\%) did not use the devices to take notes in class.

Thirty-one respondents (43\%) used their devices to search for information while in class, whereas 41 (57\%) did not use their devices for this purpose. Twenty-five respondents $(35 \%)$ used Google to look for information and two (3\%) used dictionaries on their devices to look for information. Other uses of the handheld mobile devices as reported by the respondents refer to presentations, assignments, individual projects and collaborative projects. Most respondents used their devices for assignments and individual projects, while a slightly lower number used them for presentations. The lowest number of students used the devices for collaborative projects.

Seventy-two respondents (100\%) felt motivated to learn when using handheld mobile devices. Some of the reasons they gave for this increase in motivation were that the devices made learning easier, especially when searching for information, and that they could refer to the documents downloaded to the devices when studying. Since handheld mobile devices are portable, students did not have to carry many books around. The devices could implicitly provide easy access to any information needed at any given time, thus providing possible immediate solutions. They could also facilitate access to learning sources from almost any location, so that there is no need to go to the computer laboratories or the library when far from the university.

The respondents also used handheld mobile devices to store English-related applications in case they could not get access to the library. There are various English tutor videos, quizzes that can be downloaded to learn the language, resources such as audiobooks and Beelingo.com for listening and reading, as well as English dictionaries for learning new words. The English-related applications can also be used for grammar skills and automatic grammar correction setups. The students could also download dictionaries and their prescribed English texts, such as short stories, novels and plays. Mobile handheld devices can provide access to almost all vital information pertaining to EFAL.

\section{Test results on the use of handheld mobile devices}

The second instrument that was used to collect data for this paper was a test on the use of handheld mobile devices. Twenty fewer students (52) wrote the test as compared to the 72 who responded to the questionnaire that was discussed above. The test consisted of defining concepts, converting words in American spelling to British spelling, transcribing phonetically, identifying the number of syllables in words, parts of speech and types of literary genres, and calculating averages. Test questions or statements are repeated for easy reference (see Appendix B). 


\section{Define mobile and device}

Table 4: Definition of words

\begin{tabular}{|l|l|l|}
\hline Definition & $\begin{array}{l}\text { Students who provided the } \\
\text { correct meaning }\end{array}$ & $\begin{array}{l}\text { Students who provided an } \\
\text { irrelevant meaning }\end{array}$ \\
\hline Mobile & $87 \%$ & $13 \%$ \\
\hline Device & $81 \%$ & $19 \%$ \\
\hline
\end{tabular}

\section{Definition of mobile}

Eighty-seven percent of the respondents gave the literal meaning of the test question whereas $13 \%$ gave answers that were not relevant for the study. An example of an irrelevant answer is, 'mobile is a decorative structure that is suspended so as to turn freely in the air'.

\section{Definition of device}

Eighty-one percent $(81 \%)$ gave correct answers and $19 \%$ provided definitions that were not relevant. Although the interest in user experience in industry and academia is high, there is still a lack of systematic research on the experience itself (cf. Arnold \& McDermott., 2013). Since usability tests tend to focus on task performance (cf. Arnold \& McDermott, 2013; see Appendix B), most of the students got definitions of mobile and device correct. This implies that some of the students could use their devices to look up the definitions of the words in the test.

\section{Convert the underlined words in a given paragraph to British spelling.}

The a) program started very early with the chairperson telling everyone to be b) organized. He told them hard c) labor was the d) center to great success. They also e) practiced how to f) advertise their products so that they could be recognised.

All the respondents (100\%) spelt the following words correctly: programme, organised, labour, centre, practised and advertised.

3. Write down the pronunciation of each of the following words in phonetic transcript.

Table 5: Writing words in phonetic transcript

\begin{tabular}{|l|l|l|l|l|}
\hline Question no. & $\begin{array}{l}\text { Word in phonetic } \\
\text { transcript }\end{array}$ & Pass \% & Fail \% & No response \\
\hline A & Enhance & 100 & 0 & 0 \\
\hline B & Forage & 100 & 0 & 0 \\
\hline C & Scourer & 19 & 0 & 81 \\
\hline
\end{tabular}

All the respondents (100\%) got 'enhance' and 'forage' correct. However, only $19 \%$ got 'scourer' right, while $81 \%$ did not respond to the question.

4. Give the number of syllables in each of the following words: successful, activities and labout.

All the respondents gave the correct number of syllables for 'successful', 'activities' and 'labour'. 
5. Give the parts of speech (word classes) of the following underlined words and the words in single quotes: singing, successful, dearth, benefit, Polokwane, enjoys, crime and the.

Table 6: Performance of students in Question 5

\begin{tabular}{|l|l|l|l|}
\hline Question no. & Words & Correct answer \% & Incorrect answer \% \\
\hline A & singing & 77 & 23 \\
\hline B & successful & 83 & 17 \\
\hline C & dearth & 87 & 13 \\
\hline D & benefit & 92 & 8 \\
\hline E & Polokwane & 100 & 0 \\
\hline F & enjoys & 88 & 12 \\
\hline G & crime & 100 & 0 \\
\hline H & the & 85 & 15 \\
\hline
\end{tabular}

In this question, $77 \%$ of the respondents got 'singing' correct and $23 \%$ gave incorrect answers. Eighty-three percent got 'successful' right and another $87 \%$ got 'dearth' correct. In question D, only $8 \%$ got 'benefit' incorrect. All the respondents $(100 \%)$ got 'Polokwane', 'enjoys' and 'crime' right. Only $15 \%$ got 'the' in ' $\mathrm{H}$ ' wrong.

\section{Google types of literary genres and mention four of them.}

All the respondents $(100 \%)$ mentioned the correct four literary genres, namely drama, poetry, fiction and non-fiction.

7. Give the location of the University of Limpopo and its distance from Polokwane city.

All the respondents (100\%) got the location of the University of Limpopo right and calculated its distance from Polokwane correctly.

Table 6 : Overall performance of students in the test

\begin{tabular}{|l|l|l|}
\hline No. of students & Test score & \% \\
\hline 1 & 35 & 100 \\
\hline 3 & 34 & 97 \\
\hline 20 & 33 & 94 \\
\hline 8 & 32 & 91 \\
\hline 8 & 31 & 89 \\
\hline 9 & 30 & 86 \\
\hline 2 & 29 & 83 \\
\hline 1 & 24 & 67 \\
\hline
\end{tabular}

Test scores ranged from $24(67 \%)$ to $35(100 \%)$. Regarding the overall performance of the students, one (2\%) student scored $35(100 \%)$, followed by three $(6 \%)$ who obtained 34 $(97 \%)$, and $20(39 \%)$, which was the largest number, who obtained $33(94 \%)$. This was followed by nine (17\%) students who obtained 30 (86\%). Further, eight (15\%) respondents obtained $32(91 \%)$ and another eight $(15 \%)$ obtained $31(89 \%)$. Two (4\%) obtained $29(83 \%)$, and lastly, one (2\%) obtained $24(67 \%)$, which was the lowest mark of all. All the respondents $(100 \%)$ passed the test. 
From the performance presented in Table 6, it could be deduced that the student educators can use their mobile devices effectively in a given test. Additionally, mobile devices do provide an enabling environment for students (Oriogu et al., 2018).

\section{CONCLUSION AND RECOMMENDATIONS}

Most of the UL student teachers possess handheld mobile devices, and the majority of them own smartphones. This should augur well for the use of handheld mobile devices in the learning and teaching of EFAL at UL and PDIs in a similar situation. If students need information, it can be accessed through the devices whenever the need arises. This was demonstrated and corroborated by the students who responded to the questionnaire and wrote the test on the use of handheld mobile devices.

Using mobile devices as instruments for accessing information was effectively put into practice by second-level student educators. Additionally, the mobile devices market is rapidly expanding in South Africa and these devices are becoming more and more affordable. It is therefore highly likely that there would be a proliferation of handheld mobile device usage among students even at PDIs. It could be deduced that UL students' handheld mobile devices make it possible for them to access information anywhere and at any time. The devices enable them to have easier access to learning sources such as e-dictionaries and pictures in their own time. Respondents also demonstrated that they could use the devices to access information when they are assembled in one place for purposes of learning. This is therefore in line with asynchronous and synchronous learning. Just-in-time information can also be provided by means of handheld mobile devices. Since these students are always on the move, their mode of learning should be adapted to their mobility.

Although the respondents in this study are mainly from previously disadvantaged groupings, they do possess handheld mobile devices with which they can access the internet. This conveniently creates valuable opportunities for learning and teaching to take place using handheld mobile devices. They are thus able to access information using their handheld mobile devices rather than through immobile computers.

Given the favourable factors mentioned above, the current use of mobile devices in education is likely to become more widespread as the devices become more effective in their application. It has been noted in this paper that the kind of learning that is possible through the medium of mobile devices, could become even richer and more varied as the technology improves and as mobile devices such as smartphones become much more affordable. This could also benefit students whose study budgets are limited (cf. Kukulska-Hulme, 2005: 52).

Access to and use of handheld mobile devices would put student educators in good stead for the use of the devices in English learning and teaching. It would be even more enriching if the students could own different types of devices. To some extent, sanctioning the use of the devices in class is in line with a learner-centred approach, as students tend to benefit more from the anytime and anywhere use of these devices.

The handheld mobile devices provided an extremely convenient means of obtaining essential information, and this gave the students the advantage of accessing information anywhere, at all times. This confirms that the students are ready to use the devices for learning the English language. The envisaged use of the devices should in the long term inculcate anywhere and anytime learning. This is one of the essential components among student educators as they 
will be gaining a foothold in functioning efficiently in an English language academic community.

The majority of the respondents used their handheld mobile devices to communicate with fellow students outside the classroom. This means that it is possible to use this tool as a means of teaching and learning communication between lecturers and their students. Interestingly, $100 \%$ of the respondents used the devices to search for information. As a result of what was observed in this study, it would be possible for students to browse the internet to obtain essential and useful information, and to use various applications of social media through their handheld mobile devices.

PDIs should encourage newly enrolled students to access and browse the internet using their handheld mobile devices instead of standing in long queues in overcrowded computer laboratories awaiting their turn to use desktop computers. UL may consider providing Wi-Fi everywhere around campus so that students are able to access the internet at no cost to avoid overcrowding in the computer laboratories. This would be in line with the principle of accessing information anywhere and anytime to expedite teaching and learning. Thus, student educators, especially those from disadvantaged backgrounds, would be encouraged to utilise their handheld mobile devices for learning purposes.

Since this paper focused on a sample of second-level English language student educators, all student educators in different study levels at UL could be tested and requested to complete a questionnaire on the use of handheld mobile devices. In addition, all English language students at UL could be tested and be requested to complete a questionnaire on the use of handheld mobile devices. English language lecturers who teach student educators at UL could also be interviewed about the use of handheld mobile devices. Further, the rest of the UL English language lecturers could be tested on the use of handheld mobile devices. A campus-wide UL student survey could be conducted on accessing information based on the types of devices owned by the university community. Most importantly, UL lecturers who teach languages in general, and English in particular, could first be tested and then interviewed on the significance of using handheld mobile devices in teaching and learning. The findings of this investigation should spur practitioners into activity about using tools that students already have in order to alleviate learning constraints pertaining to computer laboratories (see Methodology; cf. Vygotsky, 1978).

\section{REFERENCES}

ADOM, D, A YEBOAH \& AK ANKARA. 2016. Constructivism philosophical paradigmimplication for research, teaching and learning. Global Journal of Arts Humanitiesand Social Science, 4 (10):1-9.

ALBEDAH, F, \& CB LEE. 2017. The use ofmobile devices outside of the classroom for selfdirected learning amongfemale EFL students in Saudi Arabia. International Conference EducationalTechnologies. https://eric.ed.gov> Accessed 18 November 2019.

AMINEH, BJ \& HD ASL.2015. Review of constructivism and social constructivism.Journal of Social Sciences Literature and Language, 1 (1):9 -16.

ARNOLD, KM \& KB McDermott. 2013. Test-potentiated learning: Distinguishing between direct and indirect effects of tests. Journal of Experimental Psychology: Learning, Memory, and Cognition. 39(3):940-945.

BONK, CJ \& DJ CUNNINGHAM. 1998. Searching for learner-centered, constructivist and sociocultural components of collaborative educational learning tools. In Bonk, CJ \& KS 
King (Eds.), Electronic collaborators: Learner-centered technologies for literacy, apprenticeship, and discourse. Mahwah: NJ: Erlbaum. 22-50.

CARLESS, D. 2015. Excellence in university assessment. London: Routledge.

CHEN, XB. 2013. Tablets for informal language learning: Student usage andattitudes. Language Learning and Technology, 17(1):20-26.

DE CHAZAL, E. 2014. English for academic purposes. Oxford: Oxford University Press.

DORNYEI, Z. 2007. Research Methods in applied linguistics. Oxford: Oxford University Press.

DRURY, E. 2012. Mobile phones in the classroom: Teachers share tips. The Guardian: 4, 10 Sept.

ENGESTROM, R. 2009. Who is acting in an activity system? In Sannino A, Daniels, H \& K Gutierrez(Eds.). Learning and expanding with activity theory. https://www.cambridge.org > books. Accessed 13 June 2015.

FORD, M., \& T. LEINONEN. 2009. MobilED: A mobile tools andservices platform for formal and informal learning. http://mobiled.uiah.fi. Researchgate. Accessed 18 November 2016.

HANG, NVT, AMW BULTE \& A PILOT 2017. Interaction of Vietnamese teachers with a social constructivism-based primary science curriculum in a framework appropriate for a Confucian heritage culture. Asia-Pacific Science Education, 3(2):1-33.

GEIST, E. 2011. The game changer: Using iPads in college teacher education classes. College Student Journal, 45(4):758-768.

GUNINA, N A (Ed). 2015. Action research into teaching English in Russia's professional context. Newcastle upon Tyne: Cambridge Scholars Publishing.

KOLAN, BJ \& PE DZANDZA. 2018. Effect of social media on academicperformance ofstudents in Ghanaian universities: A case study of University of Ghana, Legon. Library Philosophy and Practice, 1-24.

KUKULSKA-HULME, A. 2005. Mobile usability and user experience. In Kukulska-Hulme, A. \& J. Taxler, (eds.) Mobile learning: A handbook for educators and trainers.45-56. London: Routledge.

LARSEN-FREEMAN, D \& M ANDERSON. 2016. Communicative language teaching in techniques and principles in language teaching ( $3^{\text {rd }}$ edition ed.) London: OUP.

LEDIGA, M. S. 2018. The use of handheld mobile devices: an exploratory study of English language student educators. University of Limpopo, M.A. Mini-dissertation.

LINN, RL \& NE GRONLUND. 2000. Measurement and Assessment in Teaching. UpperSaddle River, NJ: Prentice Hall.

LUI, M, CC NAVARRETE, E MARADIEGUE.\& J WIVAGG. 2014. Mobile learning and English language learners: A case study of using iPod Touch as a teaching and learning tool. Journal of Interactive Learning Research, 25(3):373-403.

MILLER, W. 2012. iTeaching and learning: Collegiate instruction incorporating mobiletablets. Library Technology Reports (9). Retrieved from http://web.ebscohost.com.ezproxy.stockton.edu:2048/ehost/pdfviewer/pdfviewer?sid78 fc5fe4

MISHAN, F. 2017. 'Authenticity 2.0': Reconceptualising 'Authenticity' in the digital era, In Maley, A. \& B Tomlinson (Eds). Authenticity in materials development for language learning. Newcastle upon Tyne: Cambridge Scholars Publishing. 10-24.

MOCKUS, L, H DAWSON, S EDEL-MALIZIA, D SHAFFER, J SUNG AN \& A SWAGGERTY 2011. The impact of mobile access on motivation: Distance education 
student perceptions. http://learningdesignpsuresearch/MLRTWhitePaper.pdf. Accessed 4 December 2016.

NAISMITH, L., P LONSDALE, G VAVOULA, \& M SHARPLES. 2004. Literature review in mobile technologies and learning. [Online] Available from http://www.futurelab.Accessed 13 May 2016.

NATIONAL RESEARCH COUNCIL. 1999. How people learn: brain, mind, experience, and school. Washington, DC: National Academy Press.

NGOEPE, LJ. 2017. Authentic teaching and learning materials in a South African setting. In MALEY, A \& B TOMLINSON (Eds), Authenticity in materials development for language learning. Newcastle upon Tyne: Cambridge Scholars Publishing. 177-191.

NORDIN, A, MA EMBI, RM YASIN, S RAHMAN, \& MM YUNUS. 2010. The Mobile learning readiness of the post-graduate students, 2010 EABR \& ETLC Conference Proceedings. Dublin, Ireland.

ORIOGU, CD, CI EJEMEZU \& CD OGBUIYI. 2018. The Use of mobile devices in learning foreign languages: Survey of a private university. Libraries at University of NebraskaLincoln. Library Philosophy and Practice (e-journal).Accessed 22 November 2019.

PEREZ-PAREDES, P., C ORDANANA GUILLAMON, P AGUADO-JIMENEZ, A MEURICE, G. CONOLE, J. VAN DE VYVER \& P. SANCHEZ. 2019. Mobile datadriven language learning: Affordances and learner's perception. System.

PEW RESEARCH CENTER. 2015. Survey conducted March 17-April 12 2015. Technology Device Ownership.

RAHIMI, M \& SS MIRI. 2014. The impact of mobile dictionary use on language learning. Procedia-Social and Behavioural Sciences $98 \quad$ (2014)14691474.DOI:10.1016/j.sbspro.2014.03.567. Accessed 25 November 2019.

RICHARDS, JC. 2015. The changing face of language learning: Learning beyond the $\begin{array}{lllll}\text { classroom. } & \text { RECL } & \text { Journal, } & 46 & \text { (1), }\end{array}$ http://rel.sagepub.com/cgi/doi/10.1177/0033688214561621._ncessed 29 November2019.

RICHARDS, K, SJ ROSS \& P SEEDHOUSE. 2012. Research methods for applied language studies: An advanced resource book for students. New York: Routledge.

SALOMON, G. \& D. N. PERKINS 1998. Individual and social aspects of learning. Review of Research in Learning, 23(1):1-24.

SALEH, R. \& NA ALIAS 2012. Learner needs analysis for mobile learning comic application among dyslexic children. International Journal of Education and Information Technologies, 6(2).

SHARPLES, M, D. CORLETT., S. BULLS., T CHAN, \& P RUDMAN. 2005. The student learning organiser. In A Kukulska-Hulme \& J. Traxler, Mobile learning: A handbook for educators and trainers. London: Routledge.

STOCKWELL, G. (2008). Investigating learner preparedness for and usage patterns of mobile learning. ReCALL, 20(3):253-270.

TRAXLER, J. 2007. Defining, discussing and evaluating mobile learning: the moving finger writes and having writ... International review of research in open and distance learning, Vol. 8:1-12.

UNIVERSITY OF LIMPOPO CALENDAR, 2016. Faculty of Humanities, School of Education. Sovenga: University of Limpopo.

VAVOULA, G, M. SHARPLES \& J TAYLOR. 2007. A theory of learning for the MobileAge In ANDREWS R \& C HAYTHORNWAITE (Eds), The Sage handbook of eLearningResearch. London: Sage. 
VYGOTSKY, LS. 1978. Mind in society: The development of higher psychological processes. Cambridge: Harvard University Press.

ZHANG, D \& P. PEREZ-PAREDES. 2019. Chinese postgraduate EFL learners' selfdirected use of mobile English learning resources, Computer Assisted Language Learning, DOI: 1080/09588221.2019.1662455. Accessed 26 November 2019.

ZURITA, G \& MA NUSSBAUM. 2007. Conceptual framework based on activity theory for mobile CSCL. British Journal of Educational Technology, 38(2): 211-235.

\section{BIOGRAPHICAL NOTES}

M. Sylvia Lediga is a post-graduate student in English Studies at the University of Limpopo, Department of Languages. Her research focuses on the use of technology in the English language classroom.

L. Junia Ngoepe is a senior lecturer at the University of Limpopo where she lectures English in the Department of Languages. Her research foci include L2 acquisition, assessment, materials development and evaluation. Her fields of interests lie in ESP as well as EAP. 


\section{APPENDICES}

\section{Appendix A: Questionnaire for Student Educators}

Kindly encircle appropriate responses and/or provide relevant information which best describe each aspect in the questionnaire.

1. Biographical Data

$1.1 \quad$ Gender

1.2 Grade 12 English passed (e.g. EFAL, EHL)

1.3 Grade 12 English symbol/level:

$1.4 \quad$ What is your other major subject?

2. Types of handheld devices

2.1 Type of handheld device (encircle the one(s) you have)

2.1.1 Smartphone

2.1.2 Tablet PC

2.1.3 IPhone

2.1.4 IPad

2.1.5 Other (specify)

2.2 Why did you choose this kind of device(s)?

3. General Use

3.1 Do you use your device to study English?

[Yes] [No] example.

Have you downloaded any English-learning App on your device? If yes, give an

3.2 How often do you use the device when learning? Encircle the most appropriate answer.

[Sometimes] [Often][Always]

3.3 Do you sometimes use it to look up information while in class?

[Yes] [No]

3.4 Do you use it to communicate with other students about class-related matters outside of class?

[Yes] [No]

If yes, how do you communicate? 
3.5 How do you keep track of your class schedule?

3.7 Do you use the device to look for information anywhere?

$$
\text { [Yes] [No] }
$$

3.8 Do you use the device to look for information anytime?

$$
\text { [Yes] [No] }
$$

3.9 How would you rate the usefulness of the device in your learning? Encircle your most appropriate answer.

[Very useless] [Useless] [Neither useful] [useless] [Useful]

[Very useful]

4. Classroom Use

4.1 Do you sometimes record your English class lecture?

\section{[Yes] [No]}

4.2 Do you sometimes record in-class activities?
[Yes]
$[\mathrm{No}]$

Give examples of lessons recorded.

4.3 Do you use the device to take notes in class?
[Yes]
$[\mathrm{No}]$

How do you use it?

4.4 Do you use the device to search for information while in class?

$$
\text { [Yes] [No] }
$$

How do you use it? 
5. Other Uses

5.1 Do you use the device for class presentations?

$$
\text { [Yes] [No] }
$$

5.2 Do you use the device for assignments?

$$
\text { [Yes] [No] }
$$

5.3 Do you use the device for projects?

$$
\text { [Yes] [No] }
$$

Give examples of projects

5.4 Do you also use it for collaborative projects? Yes or No [Yes] [No]

How do you use it?

6. Library Resources

6.1 Does your device have access to library resources?

[Yes] [No]

Give examples of the resources.

7. Motivation

7.1 Do you feel motivated to learn when you use the device?

[Yes] [No]

Give an explanation

8. Mention any additional information on the use of handheld mobile devices in EFAL. 


\section{Appendix B: Test on the use of handheld mobile devices}

\section{Instruction(s): Answer all questions. \\ Duration: $\quad 45$ Minutes}

1. Define the following concepts:

a) Mobile (2)

b) Device (2)

2. Convert the following underlined words in the paragraph below to British spelling:

The a) program started very early with the chairperson telling everyone to be b) organized. He told them hard c) labor was the d) centre to great success. They also e) practiced how to f) advertize their products so that they could be recognised.

3. Write down the pronunciation of each of the following words in phonetic transcript:
a) Enhance (2)
b) Forage (2)
c) Scourer (2)

4. Give the number of syllables in each of the following words:
a) Successful (2)
b) Activities (2)
c) Labor (1)

5. Give parts of speech (word classes) for each of the following underlined words and the words in single quotes:
a) She enjoys singing.
b) More students were successful in their searches.
c) The dearth of leisure time activities may lead to juvenile crime.
d) Digital natives surely benefit from using handheld devices.
e) What type of noun is 'Polokwane' in 7 below?
f) What type of verb is 'enjoys' in a)?
g) What is the plural form of 'crime' in c)?
h) What part of speech is 'the' in c)?

6. Google types of literary genres and mention 4 of them.

7. Calculate the average temperature of Polokwane for this week. 